The optimal level of balanced protein for growth in females between 20 and $50 \mathrm{~kg}$ body weight could not be determined due to a linear straight relationship between growth performance and protein level, after supplementation with lysine ( 13 and $15 \mathrm{p}$. Ioo protein). Any way it may be excepted that this level is slightly higher than that observed with castrated males An experiment is conducted for further information.

\title{
Digestibility of amino acids in the pig. Comparison of two methods of determination used in the case of wheat and barley
}

\author{
A. RÉRAT (1), P.-H. DURE ( $\left.{ }^{2}\right)$, D. BOURDON $\left({ }^{2}\right)$, Régine CAIMAES $\left({ }^{2}\right)$ \\ (1) Laboratoive de physiologie de la Nutrition, \\ (2) Station de recherches sur l'Elevage des Porcs, \\ Centre national de recherches zootechniques, I.N.R.A., \\ $7835^{\circ}$ Jouy-en-Josas (France)
}

The apparent digestibility of crude protein and the different amino-acids of two cereals (wheat and barley, $97 \mathrm{p}$. Ioo in the diet) was measured in 8 pigs with a mean weight of $49 \mathrm{~kg}$ during an experimental period of 10 days. In this trial where the intake level was the same for both cereals (I $438 \mathrm{~g}$ dry matter/day) the apparent digestibility of crude protein was higher for wheat ( 88 p. I0o) than for barley (76.I p. Ioo).

Arginine, histidine, glutamic acid or proline showed a higher apparent digestibility than nitrogen. On the contrary the apparent digestibility of threonine, valine, alanine, aspartic acid and particularly lysine was lower than that of nitrogen (the ADC of lysine was 76.2 p. Ioo for wheat and 6r.95 p. roo for barley).

The previous results were confirmed by calculation of the true digestibility taking into account the composition of the endogenous faecal nitrogen after feeding of a protein free diet.

The results of the balance trials were compared with the absorption coefficients of the different amino-acids, calculated after a protein intake of roo $g$ from recordings in the portal vein of the amounts of aminoacids absorbed during a post-prandial period of 8 hours. This method also showed that the digestion of wheat is more rapid and efficient than that of barley (absorption coefficients $=60 . \mathrm{I}$ p. I oo versus $39.5 \mathrm{p}$. I oo) but a certain number of differences appeared when it was compared with the balance method principally based on non essential nitrogen.

\section{Obtention and composition of rich protein wheat and its utilization by bacon pigs}

\author{
J.-P. BOUARD (1), J. CASTAING $\left({ }^{2}\right)$, M. LEUILLET (1), J.-Y. TIRILLY (1) \\ (1) Institut Technique des Céréales et des Iourrages, \\ 8, avenue du Président-Wilson, 75II6 Paris \\ (2) Association Gínérale des Producteurs de Mä̈s, \\ I, place Samucl-de-Lostapis, 6 fooo Pan (Iirance)
}

Wheat represents an excellent source of starch for bacon pigs and can be used without any physiological restrictions (CASTAING and LECILLET, 1973). Diets based exclusively on a current wheat variety supply already $50 \mathrm{p}$. Ioo of the proteins and $30 \mathrm{p}$. I 00 of the lysine. Thus, use of rich protein varieties should lead to larger soybean savings. 